Michał M. Bukowski, Słowa klucze w rządowej komunikacji politycznej. Perspektywa międzynarodowa, Wydawnictwo Uniwersytetu Jagiellońskiego, Kraków 2015, ss. 158

\title{
Barbara Cyrek*
}

Problematyka komunikacji politycznej jest w czasach nowych mediów niezwykle istotnym aspektem zarówno w naukach politycznych, jak i społecznych. Systemy-światy ulegają nieuchronnym transformacjom, modelując losy państw, a zarazem przez państwa będąc kształtowanymi. Ta holistyczna wizja świata, niezależnie od zróżnicowania kulturowego, uwzględnia też istnienie geokultury, czyli globalnej makrostrategii, której akceptacja na poziomie społecznym może być różna. Rządowe komunikowanie polityczne odgrywa zasadniczą rolę w tworzeniu geokultury - poprzez komunikaty rządowe władze państw mogą deklarować lojalność wobec wspólnej makrostrategii lub odstępstwo od niej, co prowadzić może do stworzenia antysystemowego sojuszu. Polityczna komunikacja rządowa ma zatem niemałe znaczenie we

\footnotetext{
* AGH w Krakowie, Wydział Humanistyczny.
}

współczesnym świecie, ba, może być dlań kluczowa.

Publikacja Stowa klucze w rzadowej komunikacji politycznej. Perspektywa międzynarodowa porusza powyższe zagadnienia. Jednocześnie jest to bardzo istotna pozycja w dorobku autora - $\mathrm{z}$ wykształcenia politologa, którego zainteresowania oscylują wokół analizy systemów-światów.

W swej pracy Michał M. Bukowski skupia się na internetowych komunikatach rządowych XXI wieku, czyniąc je materiałem do analizy współczesnej komunikacji politycznej w internecie w jej międzynarodowym aspekcie. $Z$ przyjętych założeń wynika, iż globalna makrostrategia polityczna ujawnia się poprzez treści rządowych witryn internetowych. Ideologie polityczne są tu rozumiane neutralnie - jako możliwie spójne i trwałe zestawy idei i poglądów, które mają wyjaśniać aktualną rzeczywistość. Autor skorzystał z systematycznie zbieranego materiału empirycznego, przeanalizo- 
wał go w sposób zbliżony do badań pozytywistów, a następnie zinterpretował z perspektywy bliskiej historycznemu materializmowi. Analiza koncentruje się na hasłach i słowach kluczach obecnych w tekstach witryn rządowych, to jest takich, których przedmiotem jest ogólna działalność najwyższego szczebla władzy wykonawczej w państwie, zaś podmiotem kontrolującym jest rząd danego państwa lub jego wyspecjalizowana jednostka, np. biuro prasowe. Materiał tekstowy sprowadzony został do czystego tekstu, zaś ten poddano komputerowej analizie zawartości, przy czym autor podkreśla, iż dokonał także ręcznej selekcji haseł. Brak jednak w pracy analizy językoznawczej czy obrazu świata, przyjęta jest natomiast ogólna perspektywa konstruktywistyczna. Jako że akty międzyludzkiej komunikacji językowej to między innymi procesy wytwarzania świata, można przyjąć za autorem, iż ład międzynarodowy jest konstruowany za pomocą słów kluczy w komunikacji politycznej. Badane tu konstrukty są zatem stworzone $\mathrm{z}$ haseł, werbalnych symboli politycznych. W badaniu wykorzystano jedynie teksty w języku angielskim, lecz przedmiotem wnioskowania nie jest tutaj kultura anglosaska. Jest nim natomiast geokultura, której nie należy mylić z kulturą globalną. Jak pisze sam autor, geokultura to „przyjęte reguły gry”, które mogą być zorientowane na akceptację lub zmianę systemu. Geokultura mierzona jest za pomocą frekwencji słów kluczy, a autor bada jej powiązanie z cechami kapitalistycznej gospodarki-świata. Warto jednak pamiętać, iż przeprowadzona w ten sposób analiza wymaga ostrożnych wniosków. Określanie ideologicznego oblicza rządów na podstawie frekwencji i zestawień haseł sztandarowych nie może być jednoznaczne, gdyż konteksty społeczne i prawdziwe intencje nadawcy odgrywają zasadniczą rolę. Przy czym nie jest możliwe niebudzące wątpliwości poznanie tych drugich.

Analizie poddane zostały 43 słowa klucze w tekstach opublikowanych w latach 2006 i 2012 na rządowych witrynach 66 państw. 43 słowa klucze zostały zredukowane do 7 czynników. Tym sposobem w książce przedstawiono siedem dyskursów: konfliktu, Globalnej Północy, Globalnego Południa, wojny z terrorem, jedności i stabilizacji, postkolonializmu oraz centrystycznego liberalizmu. Nawiązując do prac Wallersteina, autor do tematu podchodzi unidyscyplinarnie, to jest bez rozdziału tego, co polityczne od tego, co ekonomiczne i tego, co historyczne. W pogłębionej analizie sprawdza on związek pomiędzy dyskursem a regionalnym i geopolitycznym otoczeniem państwa.

Przedstawione badania wykazują, iż struktura znaczeniowa słów kluczy nie uległa zasadniczej zmianie po kryzysie, jaki miał miejsce w 2008 roku. Różnorakie zestawienia danych ukazują liczne zależności między sytuacją gospodarczą, geograficzną czy historyczną poszczególnych państw. Można dzięki temu dostrzec powiązanie dyskursu konfliktu z przeszłością kolonialną - jest on wyższy w państwach zależnych niegdyś od ZSRR, a niższy w państwach ko- 
lonialnie związanych z Wielką Brytanią. Czynnik siły ekonomicznej państwa wydaje się najważniejszy dla dyskursu o wojnie z terrorem. Z kolei dyskurs centrystycznego liberalizmu, teoretyczna podstawa geokultury nowoczesnego systemu-świata okazał się niemal niezależny od badanych czynników, co potwierdza jego w pewnym stopniu uniwersalny charakter. Większość rządów chce się po prostu komunikować w dyskursie rządu prawa. Choć i od tego zmienne regionalne ujawniają po zagregowaniu pewne zależności. Te i inne zależności można dostrzec dzięki nowoczesnej analizie zawartości, wykorzystanej przez autora.

Zgodnie z założeniami konstruktywistycznymi, komunikacja polityczna, czyli proces perswazyjnego negocjowania treści dotyczących polityki, jest zagadnieniem nie tylko odzwierciedlającym kształt geokultury, lecz także wpływającym na systemy-światy. Przyjęta przez autora hipoteza badawcza zakładała istnienie powszechnie przyjętego w rządowej komunikacji politycznej zestawu haseł. Przeprowadzona analiza dowiodła, iż nie tu można mówić o ściśle uniwersalnym rozpowszechnieniu słów kluczy. Od jakich czynników zależy więc nasycenie nimi w rządowej komunikacji politycznej? Teoria systemów-światów przypisuje tutaj znaczącą rolę czynnikom ekonomicznym. Publikacja częściowo obala te założenia, dowodząc zasadniczego znaczenia zmiennych geopolitycznych i regionalnych. Autor zwraca jednak uwage na programowo historyczne granice perspektywy systemów-światów, co pozwala zachować tę teorię w postaci uaktualnionej z założeniem, iż ład, który ona pierwotnie opisywała, należy już do przeszłości.

Praca składa się z czterech rozdziałów, z których pierwszy poświęcony jest założeniom metodologicznym. Kolejno Michał M. Bukowski objaśnia czytelnikom przyjęte przez siebie definicje, by w rozdziale trzecim przedstawić wyniki swojej analizy w licznych tabelach (39) i wykresach (25). W ostatnim, kluczowym rozdziale, autor interpretuje wyniki swych badań w odniesieniu do teorii systemów-światów.

Autor posługuje się licznymi przykładami z historii, dzięki czemu w swojej pracy przedstawia nie tylko pewne zależności, ale też ich realny wpływ na dzieje systemu-świata. Historyczny kapitalizm w ramach teorii systemów-światów jest skazany na upadek. Nie jest możliwe jednoznaczne określenie nowego, nadchodzącego systemu-świata (czy systemów-światów). Czy ujawnią się nowe sprzeczności? A może przyjdzie nam zmierzyć się z tymi samymi, lecz przy innej konfiguracji geopolitycznej? Ujawniona w niniejszej pracy rola czynników regionalnych może być tutaj kluczowa. Dodanie do zestawienia słów kluczy z najnowszych komunikatów rządowych może pozwolić na określenie miejsca, w jakim aktualnie znajduje się świat. 